(C) 2015

\author{
Харак Р. М., кандидат технічних наук, \\ Левчук В. І., кандидат технічних наук, \\ Лихвенко С. П., стариий викладач
}

Полтавська державна аграрна академія

\title{
ЕКСПЕРИМЕНТАЛЬНЕ ДОСЛІДЖЕННЯ КЕРОВАНОСТІ ТА ТЯГОВИХ ПОКАЗНИКІВ ТРАКТОРА КЛАСУ 14 КН НА ОРАНЦІ
}

\section{Рецензент - кандидат технічних наук В. В. Лоснко}

Представлені результати експериментального дослідження керованості, тягових та економічних показників орного атретату в складі трактора МТЗ50 із плугом ПН 3-35Б на стерні з диференціальним та заблокованим міжколісним приводом заднього моста. Спираючись на дані аналізу результатів дослідження, встановлено погіршення керованості трактора у випадку блокованого приводу порівняно із диференціальним. Разом з тим зафіксоване значне зменшення буксування $i$ зростання тягового ККД атретату (близько $10 \%$ у у випадку заблокованого приводу. Проведені також дослідження трактора за тяговою характеристикою під час руху у борозні глибиною 30 см (праві колеса) і по стерні (ліві колеса) на III, IV i V передачах, результати яких дають змогу зробити висновки про суттєве покращання тягових показників трактора в разі блокованого міжколісного приводу.

Ключові слова: обертаючий момент, оранка, плуг, трактор, сила тяги, витрата палива, тягова характеристика, керованість, потужність, стерня, бокові сили, кут нахилу трактора, керовані колеса, тяговий ККД.

Постановка проблеми. На тракторах виробництва Мінського тракторного заводу класу 14 20 кН встановлена система блокування ведучих коліс заднього моста 3 гідравлічним приводом. Вона дає змогу виконувати різні тягові операції із блокованим або диференціальним приводом 3 метою покращання тягово-зчіпних показників сільськогосподарських агрегатів.

У процесі оранки праві колеса трактора знаходяться у борозні, а ліві - на стерні, тобто у різних умовах зчеплення. Крім того, відбувається перерозподіл ваги трактора між правими і лівими колесами, внаслідок його поперечного нахилу, що також впливає на тягово-зчіпні якості орного агрегату. Робота агрегату в таких умовах впливає також на керованість трактора.

У зв'язку з цим дослідження впливу блокованого приводу на тягово-зчіпні та економічні показники і керованість орного агрегату викликає певний інтерес.
Аналіз останніх досліджень і публікацій, у яких розглядасться поставлена проблема. Блокування міжколісного диференціалу застосовується в конструкціях багатьох відомих тракторобудівельних компаній світу: CAT, CASE, NewHolland, JohnDeer, Kubota, ХТЗ, ЛТЗ і т. д. Починаючи з 1968 року, система блокування міжколісного диференціалу з гідравлічним приводом запроваджується й на тракторах МТЗ. Свого часу дослідження ефективності іiі дії проводились на кафедрі «Трактори і автомобілі» Полтавського державного сільськогосподарського інституту за технічним завданням Мінського тракторного заводу [1].

Не всі результати досліджень цієї госпрозрахункової тематики, що виконувались колективом кафедри під керівництвом Д. І. Мельникова, до цього часу проаналізовані. Вони можуть мати об'єктивний інтерес як у сьогоденні, так і в майбутньому в разі появи нових матеріалів і технологій для тракторних колісних модулів.

Керованість та стійкість руху трактора в умовах різного зчеплення коліс у випадку їх блокованого та диференціального приводу досліджувалось на базі рушія МТ3-80 [2]. Результати досліджень розподілу обертаючих моментів між ведучими колесами в процесі оранки [3] дали можливість дійти до висновку, що керованість трактора в разі заблокованого міжколісного приводу погіршується, а тягово-зчіпні показники покращуються. Блокований привід також призводить до збільшення витрати палива.

Метою дослідження було встановлення впливу блокування міжколісного диференціалу трактора МТЗ-50 з плугом ПН 3-35Б у процесі оранки стерні озимої пшениці на його керованість та тягово-зчіпні й економічні показники.

Для визначення критеріїв керованості трактора оранка здійснювалась на глибину 15, 20, 25 см і роботі агрегату на третій передачі.

Для оцінювання тягово-зчіпних показників трактора оранка виконувалась на глибину $30 \mathrm{~cm}$.

Також проводились дослідження трактора за 


\section{TEХНIЧНІ НАУКИ}

тяговою характеристикою на III, IV i V передачах під час руху у борозні глибиною 30 см (поперечний нахил трактора був у межах $12^{0} \pm 30^{\prime}$ ) за блокованого і диференціального приводу ведучих коліс. Дослідження проводились згідно 3 договорами з Мінським тракторним заводом [1].

Замірялися обертаючі моменти на ведучих колесах трактора, бокові сили і сили опору коченню керованих коліс та їх кут повороту, оберти колінчастого валу, буксування, витрата палива, швидкість руху, сила тяги на гаку. Інші показники визначались за формулами, представленими в нашій статті «Експериментальне дослідження стійкості прямолінійного руху трактора в умовах різного зчеплення ведучих коліс» [2].

Матеріали і методи дослідження. Для отримання необхідних даних на трактор МТ3-50 були встановлені тензометричні пристрої, які забезпечували можливість безпосередньо заміряти значення обертаючих моментів на ведучих колеcax трактора та їх частоту обертання, частоту обертання колінчастого валу двигуна, швидкість руху трактора, витрату палива, кут повороту керованих коліс, бокові сили та сили опору коченню керованих коліс. Параметри дослідження записувались на осцилограми 3 використанням тензометричної лабораторії на базі автомобіля ГАЗ-53А.

Осцилограми оброблялись за стандартною методикою з використанням комп'ютерної техніки.

Тягова характеристика трактора на оранці отримувалась за стандартною методикою [6]. В якості навантаження на гаку застосовувався трактор МТ3-50, а навантаження змінювалось шляхом увімкнення різних передач на цьому тракторі. Показники тягової характеристики визначались за формулами, представленими в нашій статті «Аналіз роботи орного агрегату з трактором МТЗ-80 із диференціальним і блокованим міжколісним приводом» [3].

Результати досліджень. Реєстрація силової дії навісного плуга ПН 3-35Б на трактор МТ3-50 проводилась за трьох значень глибини оранки: 15,20 і 25 см на третій передачі. Під час навантажень на гак трактора, близьких до номінального, коли сумарний обертовий момент на ведучих колесах $\Sigma \mathrm{M}_{\mathrm{K}}=10,9-11,94 \mathrm{\kappa H} \cdot \mathrm{M}$, сумарні значення бокових сил, що діють на керовані колеса, мали порівняно невелику величину $\Sigma \mathrm{P}_{\text {бп }}=0,539$ 0,955 кН. Необхідний стабілізуючий момент, створюваний боковими силами керованих коліс, не перевищував при цьому величини $\mathrm{M}_{\text {ст }}=\mathrm{M}_{\text {пов }}$ $=1,3-2,0$ кН·м, що свідчить про порівняно невелику величину відхиляючого моменту, діючого 3 боку плуга на трактор.

Бокові сили, діючі на керовані колеса, розподілялись таким чином, що на правому колесі, що рухається у борозні, на всіх навантажувальних режимах бокова сила була у 1,3-1,5 рази більша, ніж на польовому колесі, що рухається по стерні.

Стосовно сил опору коченню $\mathrm{P}_{\text {fп, }}$ що діють у площині повернутих керованих коліс, то зменшення величини цих сил під час зростання глибини оранки у значній мірі пояснюється розвантаженням цих коліс за збільшення тягового навантаження на трактор. Кути повороту керованих коліс, що забезпечують виникнення бокових сил для зрівноваження відхиляючого моменту $\mathrm{M}_{\text {от }}$, створюваного плугом, за даними досліджень, були у межах $\alpha=2,3-4,8^{0}$, що значно нижче кута повороту керованих коліс, за якого автоматично вимикається блокування міжколісного диференціала.

Середні зусилля тракториста на рульовому колесі під час оранки, за даними досліджень, не перевищували 13,5 Н, що свідчить про достатню легкість керування трактором. Однак слід мати на увазі, що навантаження на тракториста по керуванню орним агрегатом зростає, тому що він повинен постійно тримати керовані колеса повернутими на кут $2,3-4,8^{0}$, а також тіло тракториста постійно нахилене вправо під кутом близько $12^{0}$ під час оранки на глибину $30 \mathrm{~cm}$.

За результатами дослідження тягових показників трактора під час виконання оранки на глибину 30 см отримані наступні дані. Трактор із розблокованим диференціалом розвиває максимальну потужність на гаку $\mathrm{N}_{\Gamma}=18,4$ кВт за сили тяги $\mathrm{P}_{\Gamma}$ близько 14 кН, при цьому буксування $\delta=0,34$. Тяговий ККД трактора у цьому режимі становить $\eta_{\mathrm{T}}=0,54$.

Під час роботи агрегату в цих же умовах у випадку заблокованого диференціала потужність на гаку збільшилась до 26,2 кВт (на 42,4 \%), буксування зменшилось до 0,1 , а тяговий ККД зріс до 0,60 (на $11 \%$ ).

Зростання потужності на гаку і тягового ККД у випадку заблокованого диференціала здійснилося в основному за рахунок зменшення буксування (майже у 3,4 рази) і підвищення внаслідок цього швидкості агрегату з 1,36 до $1,75 \mathrm{~m} / \mathrm{c}$ (на $28,7 \%$ ). Отже, аналіз тягових показників орного агрегату під час оранки показує ефективність застосування блокованого міжколісного приводу трактора. Аналізуючи складові тягового ККД (рис. 1, 2), можна побачити, що ККД трансмісії

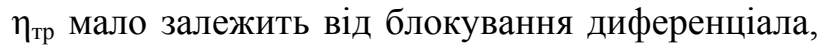
але збільшується від 0,80 до 0,86 у випадку зростання сили тяги $\mathrm{P}_{\Gamma}$. 


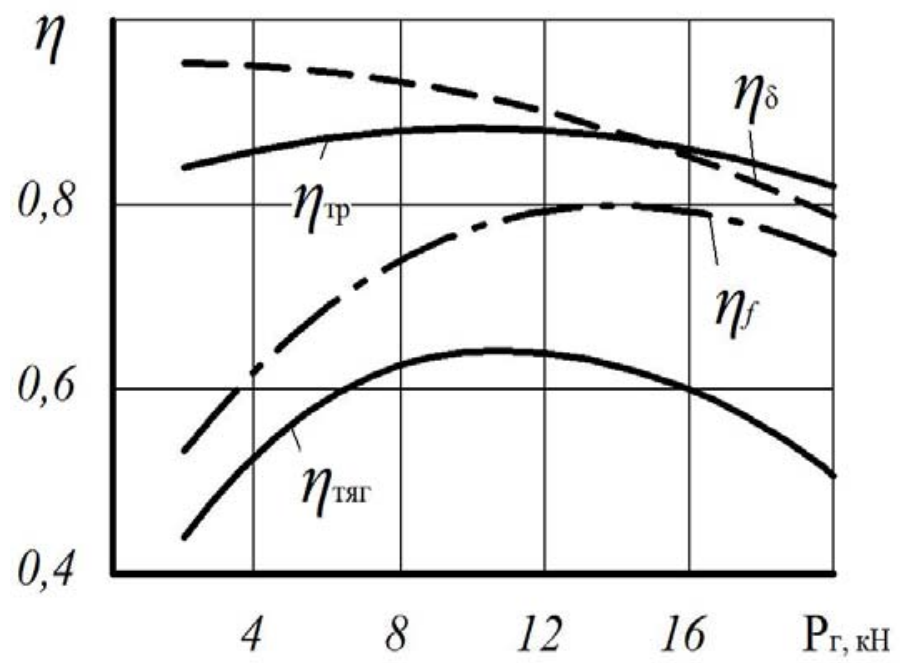

Рис. 1. Складові тягового ККД у разі блокованого міжколісного приводу в процесі оранки

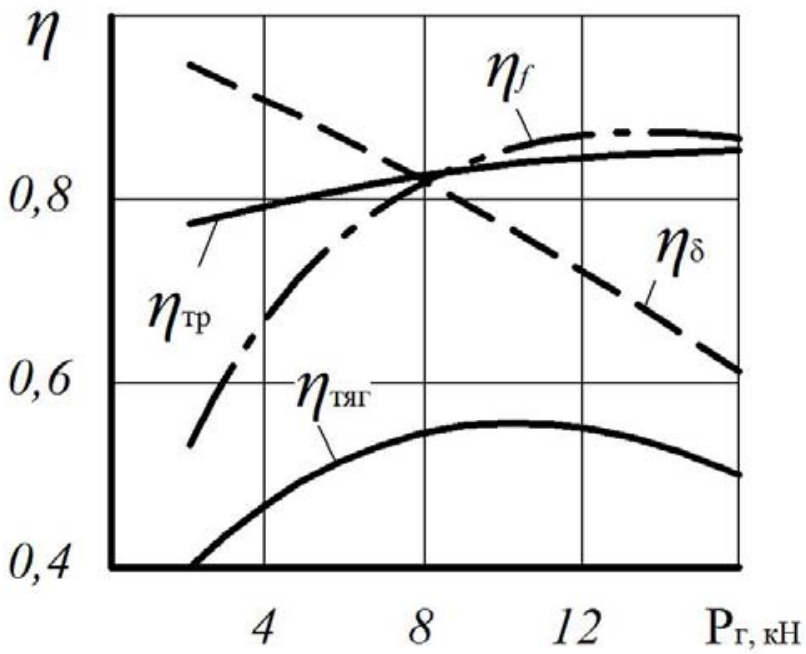

Рис. 2. Складові тягового ККД за диференціального міжкколісного приводу в процесі оранки

ККД $\eta_{\delta}$, що враховує втрати на буксування, зменшується під час збільшення зусилля на гаку: за розблокованого приводу - від 0,97 до 0,60 ; у разі заблокованого - від 0,97 до 0,80 .

ККД, що характеризує втрати, пов'язані з ро-


за $\mathrm{P}_{\mathrm{r}}=2$ кН до 0,88 за $\mathrm{P}_{\mathrm{r}}=13$ кН у випадку заблокованого диференціала. Блокування диференціала призводить до підвищеного деформування шин і опорної поверхні під час кочення ведучих коліс, унаслідок чого збільшуються енерговитрати на роботу заблокованих ведучих коліс, але це компенсується значним збільшенням тягових властивостей і зменшенням буксування трактора.
Аналіз тягової характеристики трактора на III, IV i V передачах в умовах, коли праві колеса трактора рухаються у борозні глибиною $30 \mathrm{~cm}$, а ліві - по стерні, дає змогу зробити наступні висновки.

За диференціального міжколісного приводу (рис. 3) на III передачі забезпечується максимальна сила тяги на гаку $\mathrm{P}_{\Gamma}=20$ кН під час буксування $\delta=0,44$ в той час, коли за такої ж сили тяги i блокованого міжколісного приводу (рис. 4) буксування становить 0,164 , тобто у 2,68 рази менше, а максимальна сила тяги 22 кН під час буксування $-0,260$. 


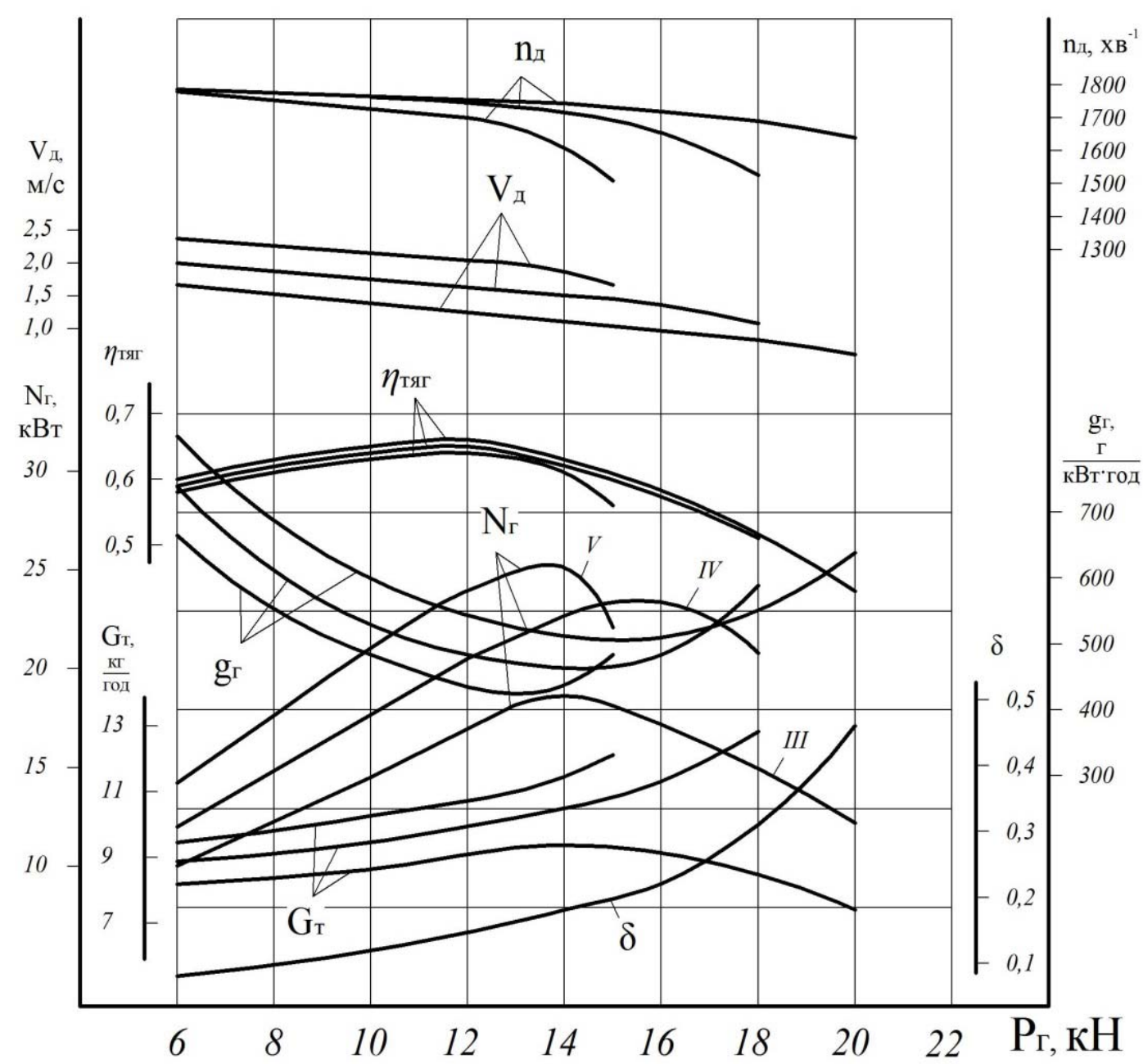

Рис. 3. Тягова характеристика трактора МТЗ-50 за диференціального міжкколісного приводу

За номінального значення сили тяги на гаку трактора (14 кН) на III передачі і диференціальному приводі буксування становить 0,16 , а у випадку блокованого приводу - 0,096, швидкість руху трактора - відповідно 1,33 і $1,55 \mathrm{~m} / \mathrm{c}$, тяговий ККД - 0,63 і 0,69. Отже, продуктивність агрегату в разі блокованого приводу на III передачі і номінальному навантаженні на гаку 14 кН зростає на $16,54 \%$ в основному за рахунок зменшення буксування, водночас витрата палива за годину $\mathrm{G}_{\mathrm{T}}$ зростає на $8,86 \%$. Питома гакова витрата палива $\mathrm{g}_{\text {г }}$ в випадку блокованого приводу на 21 \% більша, ніж за диференціального.

Ha IV передачі у разі блокованого приводу трактор розвиває максимальну силу тяги на гаку 20 кН, а за диференціального - 18 кН, продуктивність зростає у випадку блокованого приводу i номінального навантаження 14 кН на $11,11 \%$, а витрата палива за годину збільшується на $11,59 \%$, питома витрата не змінюється. Тяговий ККД за диференціального приводу становить 0,62 , а у випадку блокованого - 0,68.

На V передачі за диференціального приводу максимальна сила тяги трактора становить $15 \mathrm{\kappa H}$, а в разі блокованого - $16 \mathrm{\kappa H}$, продуктивність у випадку блокованого приводу i номінального навантаження зростає на 9,09\%, а витрата палива за годину збільшується на $12,91 \%$, питома витрата істотно не змінюється.

Отже, за результатами аналізу тягових та економічних показників трактора МТ3-50 за експериментальною тяговою характеристикою на оранці встановлено, що блокований привід дає змогу збільшити максимальну силу тяги на гаку, зменшити буксування і підвищити продуктивність за номінальної сили тяги на гаку на 9-12\%. Водночас застосування блокованого приводу призводить до зростання годинної витрати палива в межах підвищення продуктивності, у порівнянні з диференціальним приводом. 




\section{Рис. 4. Тягова характеристика трактора МТ3-50 у випадку блокованого міэкколісного приводу}

\section{Висновки:}

1. Під час оранки стерні трактором МТ3-50 із плугом ПН 3-35Б для забезпечення стійкого руху трактора у борозні трактористу необхідно тримати передні колеса трактора повернутими на кут $2,3-4,8^{0}$ залежно від глибини оранки. Середні зусилля на рульовому колесі не перевищують $13,5 \mathrm{H}$.

2. У процесі оранки на глибину 30 см у разі заблокованого міжколісного приводу буксування трактора порівняно 3 диференціальним приводом зменшилось на $11 \%$, а тяговий ККД зріс на $11 \%$, що свідчить про позитивний вплив блокування на тягові показники орного агрегату.

3. Блокування міжколісного диференціала призводить до підвищеного деформування шин ведучих коліс трактора і опорної поверхні, внаслідок чого збільшуються енерговитрати на ро- боту ходової частини, але це компенсується зменшенням буксування і покращанням тягових показників орного агрегату. Водночас спостерігається зростання витрати палива за годину у разі заблокованого приводу.

4. Аналіз тягових та економічних показників трактора МТ3-50 за тяговою характеристикою під час руху правих коліс у борозні глибиною 30 см, а лівих - по стерні дає можливість спостерігати збільшення максимальної сили тяги на всіх передачах у разі заблокованого приводу задніх коліс, зменшення буксування, зростання тягового ККД і продуктивності (в основному за рахунок зменшення буксування).

У випадку заблокованого приводу годинна витрата палива зростає практично адекватно зі збільшенням продуктивності, а питома витрата майже не змінюється. 


\section{БІБЛІОГРАФІЯ}

1. Исследование управляемости и нагруженности силовой передачи трактора кл. 1,4 ТС с автоблокирующимся дифференциалом : отчеты о НИР / Полтавский сельхозинститут. - МТЗ. №517. - Полтава, 1973.

2. Лихвенко С. П., Харак Р. М. Експериментальне дослідження стійкості прямолінійного руху трактора в умовах різного зчеплення ведучих коліс / С. П. Лихвенко, Р. М. Харак // Вісник Полтавської державної аграрної академії. - 2012. №1. - C. 178-180.

3. Лихвенко С. П., Харак Р. М. Аналіз роботи орного агрегату з трактором МТ3-80 із диференціальним і блокованим міжколісним приводом / С. П. Лихвенко, Р. М. Харак // Вісник Полтавської державної аграрної академії. - 2013. - №3. C. 171-174.
4. Мельников Д. И. Экспериментальное исследование тягових свойств колесного трактора кл. $1,4 \mathrm{TC}$ с блокирующимся дифференциалом / Д. И. Мельников, Г. Ф. Скоробагатый, В. Ф. Синельник // Тр. Харьк. с-х. ин-та им. В. В. Докучаева. - Т. 193. - Харьков, 1974. - С. 50-55.

5. Скоробагатый Г. Ф. Исследование нагруженности ведущих полуосей трактора МТЗ-80 с автоблокирующимся дифференциалом на пахоте. Совершенствование конструкций, улучшение ремонта и эксплуатации сельськохозяйственних машин / Г. Ф. Скоробагатый, С. П. Лыхвенко, А. И. Пилипенко // Тр. Харьк. с-х. ин-та им. В. В. Докучаева. - Т. 215. - Харьков, 1976. - С. 57-62.

6. Тяговые характеристики сельськохозяйственных тракторов : [альбом-справочник]. - М. : Россельхозиздат, 1979. - 240 c. 